\title{
REGULATING THE TRANSPORTATION OF DANGEROUS GOODS
}

\author{
E.M. VOMBERG*
}

\begin{abstract}
The law relating to the transportation of dangerous goods is a complex combination of numerous statutes. The new Transportation of Dangerous Goods Act is intended to be an all-inclusive regulatory scheme. The author points out many problems inherent in the Act and suggests that they are a result of the Act being passed in response to an urgent situation rather than as a result of foresight. The author reviews the current legislation, discusses the reforms contemplated by the Act and presents recommendations.
\end{abstract}

\section{INTRODUCTION}

Recent events such as the 1979 Mississauga train derailment and the decision of the Alberta government to promote the development of a treatment plant for hazardous wastes have served as foci for public concerns over dangerous substances in general, ${ }^{1}$ and more specifically, their transportation.

In Alberta, tremendous growth in the petrochemical and agricultural chemical sectors has resulted in similar increases in the amounts of these products transported throughout the Province. Motor transport of petroleum products, bulk liquids, dry chemicals and minerals increased almost $70 \%$ between 1973 and $1978 .^{2}$ Nationwide statistics are similar. While not all these cargoes could per se be considered to be hazardous, the growth rate in general transportation levels reflect a significant increase in the transportation of dangerous goods.

Two primary factors are responsible for the growth in dangerous goods transport in recent years: increased market demands and new legislation. About 1,200 of the 50,000 to 100,000 chemicals in current use are considered dangerous. ${ }^{3}$ The industry has shown steady growth; several hundred to a thousand new chemicals are brought into commercial production each year. ${ }^{4}$ In spite of the recent economic downturn, the potential for further growth in this sector of the economy remains good. Not only are new products being created, but new markets are being developed for those currently in production.

- B.E.S., LL.B. Articling with the Department of the Attorney-General of Alberta in Calgary. This paper was written as a research project for the Environmental Law Centre, funded by the Alberta Law Foundation.

1. "Toxic" or "dangerous" substances can be defined generally as those:

... which can cause death, disease, behavioral abnormalities, cancer, generic mutations, physiological or reproductive malfunctions or physical deformities in any organism or its offspring, or which can become poisonous after concentration in the food chain or in combination with any other substance.

Agreement Between Canada and the United States of America on Great Lakes Water Quality, 1978 Treaty Series 1978 No. 20 Art. I(v).

2. Canadian Transport Commission The Alberta Trucking Industry Tables-B6-9.

3. Marten, B. M., "Regulation of the Transportation of Hazardous Materials: A Critique and a Proposal"' (1981) 5 Harv.Env.L.Rev. 345.

4. Castrilli, J., "Toxic Chemical Control in Canada: An Analysis of Law and Policy" presented at Roundtable Discussions on Toxic Chemicals Law and Policy in Canada 2. 
Concerns over hazardous waste disposal practices across North America have led to the introduction of a series of statutes designed to strictly control the handling and treatment of these substances. An integral component of many of these schemes is the promotion of centralized treatment, recycling and disposal facilities. Combined with the unsuitability of many current disposal sites, these programs will inevitably increase the amounts of hazardous wastes being transported.

Given the volume of dangerous goods transported within Alberta, it appears more a matter of luck than planning that there have not been any serious incidents to date. ${ }^{5}$ According to the Motor Safety Branch of Alberta Transportation, "Over the past three years (1978 - 1980), approximately $11 \%$ of all tractor trailers involved in accidents were transporting hazardous loads."'6

When a tank truck is involved in an accident, the chances of the load being spilled are uncomfortably high. One study noted that of 24 accidents involving oil tank trailers, 14 resulted in spills, 8 involved empty units, and in only two were the cargoes retained.?

The objectives of a dangerous goods transportation policy are to minimize the probability of accidents and to mitigate their impact. Four primary risk factors must be considered:

1. Volumes of materials transported: The quantity of dangerous goods being transported is steadily increasing. Given consistent levels of controls, as traffic volumes increase, so do the chances of accidents. Accordingly, as traffic volumes increase, so does the necessity of imposing further regulation to minimize risks.

2. Chemicals carried: The nature of the substances carried must also be regarded in determining acceptable risk levels. The accidental release of relatively inert chemicals, even in large quantities could be better tolerated than the spill of even minute amounts of extremely dangerous substances.

3. Costs/benefits: Transport regulators are quite willing to admit that ideal transport safety regulations are too expensive to warrant implementation, even though less than perfect controls will cost lives. ${ }^{8}$ It is also recognized that if the costs of compliance with standards exceed the costs of avoidance (i.e. penalties), standards will be ignored. It therefore becomes imperative for regulatory bodies to establish the safest possible standards which can be most effectively used by industry.

5. This is not to say that potentially disasterous incidents have not occurrred. Fortunately, no large scale evacuations of the sort experienced by Mississauga residents have been necessary in Alberta. However, in June 1982, several hundered people were evacuated from Blairmore, Alberta, after a train derailment. Army demolition experts were called in to deal with a tank-car full of propane. Human error was later ruled to be the cause of that accident.

6. Mercer, J., Alberta Road Traffic Accident Information 1978-19802.

7. Report of the House of Representatives Standing Committee on Road Safety (Australia) Heavy Vehicle Safety 16

A recent report from Alberta Environment indicates that over one third of all hazardous material spills in the province are transport related. See 1981 Hazardous Materials Spills Summary 13.

8. Railway Transport Committee, Canadian Transport Commission. Show Cause Hearing Decision on Railway Safety (1981) 16. 
4. Human constraints: In Alberta, about $75 \%$ of all accidents involving trucks are caused by human error. ${ }^{9}$ Lack of proper training, alcohol and drug abuse, and fatigue are constant risks. Imposition of improved training and licensing requirements for all drivers would only be a partial solution.

Aside from technical and economic considerations, regulation of dangerous goods transport involves complex legal issues. Matters of jurisdiction, both between governments and among government departments, unnecessarily complicate regulatory procedures. Different standards in different provinces and countries make transportation systems inefficient. Reforms, through new, comprehensive legislation, are only now being implemented.

This paper will review the current legislative scheme, briefly look at the American regulation of dangerous goods transport, discuss the reforms contemplated by the new Transportation of Dangerous Goods Act and finally, present conclusions and recommendations.

\section{CURRENT REGULATION}

\section{A. INTERNATIONAL}

A high degree of international co-operation is necessary for the controlled, yet viable traffic in dangerous materials. Foremost in the field in promoting these goals is the United Nations Environment Program (UNEP). Its work has proved invaluable: According to Dr. N. Brown of UNEP, classification of toxic substances and promotion of international standards for testing chemicals have proven to be among UNEP's most outstanding successes. ${ }^{10}$ Through the work of this agency, several countries can now rely on the testing results from other areas and utilize standard guidelines in establishing safety parameters in transportation regulation." 1

The HAZCHEM lists of chemicals developed by UNEP have been adopted in Transport Canada's Emergency Response Guide For Dangerous Goods. ${ }^{12}$ This comprehensive volume outlines appropriate responses to assorted chemical spills, emphasizing health and environmental protection. It is anticipated that this list will be incorporated in the regulations under the new Transportation of Dangerous Goods Act. ${ }^{13}$

At the international level, uniform treaties delineate liabilities between carriers and shippers. ${ }^{14}$ While these treaties are effective, weaknesses do

9. Supra n. 6, Table III.

10. Speech by Dr. Brown 4 June 1982, Calgary, Alta. at symposium on Water: Our Unacknowledged Resource.

11. For example, Canada, lacking adquate testing facilities, depends on results from American labs. This reliance is far from ideal, especially in light of revelations that some American tests have been confabulated. As a result of scandals over forged pesticides tests, new criteria for international cooperation in dangerous materials testing may be formulated.

12. HAZCHEM Emergency Response Guide for Dangerous Goods Ministry of Supplies and Services 1977 Government of Canada Catalogue \#TP-1987.

13. S.C. 1980, C.36.

14. See, for example, the Hague Rules which form part of the Brussels Convention. These rules are currently being updated by the United Nations Commission on International Trade Law. 
exist. In the context of establishing liabilities for dangerous good transport, protection for detrimentally affected third parties would be an asset. However, the absence of such protection is apparent in many transport related statutes and treaties.

Other international organizations such as the International Aviation Transport Association (IATA) play significant roles in controlling dangerous goods transport. The IATA Restricted Articles Regulations adopted by member countries (including Canada), specify technical performance criteria for international air transport of these materials.

Due to the proximity and interdependence of Canadian and American markets, efforts must be made to ensure compatability in the transportation of dangerous goods between the two countries. Formerly, all cooperation was at an informal level, with transport officials agreeing among themselves what criteria from across the border would be acceptable. This led to a state of affairs in which "international movement of hazardous chemicals was virtually unregulated."15 Fortunately, legislative changes in both countries now ensure that international shipments of dangerous goods meet identifiable standards. These new laws stipulate that trans-boundary shipments must meet or be in substantial compliance with regulations in each jurisdiction through which the cargo travels. If properly enforced, these statutes should greatly enhance safe transportation of these materials.

\section{B. FEDERAL}

The Canadian Transport Commission (CTC) has a myriad of powers under assorted statutes. Under section 21 of the National Transportation Act, ${ }^{16}$ the CTC has a duty to enforce the provisions of that Act, the Railway Act, ${ }^{17}$ the Aeronautics Act ${ }^{18}$ and the Transport Act. ${ }^{19}$ Limited powers over marine transport are given to the CTC under Part II of the Transport Act. In a similar fashion, section 23 of the Atomic Energy Control Regulations ${ }^{20}$ gives the Commission authority over transboundary shipments of radioactive goods.

Although it has not yet been utilized, current indications are that section 36 of the National Transportation Act may be used to allow the CTC to regulate extra-provincial motor transport of dangerous goods. The CTC, however, has no jurisdiction over military transportation. As well, most of the provisions of the Canada Shipping Act, ${ }^{21}$ including those concerning dangerous goods, are beyond the ambit of the Commission. A brief overview of the relevant acts and regulations is necessary to show not only the distribution of power but also to indicate how problems can arise.

15. Kupchanko, E. "Strategy for Management of Toxic Substances in Alberta" presented to Short Course on the Significance, Analysis, and Control of Toxic Organic Substances in Wastewater 8.

16. R.S.C. 1970 , c. N-17.

17. R.S.C. 1970 , c. R-2.

18. R.S.C. 1970 , c. A-3.

19. R.S.C. 1970 , c. T-14.

20. C.R.C. vIII c. 365, under the Atomic Energy Control Act, R.S.C. 1970, c. A-19.

21. R.S.C. 1970 , c, S-9. 


\section{Aeronautics Act 22}

Sections 6, 10 and 14 of this Act enable the CTC to regulate the industry both under this Act and under the National Transportation Act. Section 800 of the Air Regulations ${ }^{23}$ is the only provision concerning air movements of dangerous goods. This section is very innocuous, merely stating that these goods are to be shipped in a manner not endangering the passengers or crew of aircraft. De facto regulation is found in the IATA Restricted Articles Regulations adopted by the Commission as the applicable standard.

Upon conviction for a breach of the Act or Regulations, penalties include fines of up to $\$ 5,000.00$ and revocation of operating licences. ${ }^{24}$ Many offences under the Act are considered to be absolute liability offences, removing the necessity of proving that the violator intended to breach the provisions. ${ }^{25}$ No cases on improper transportation of dangerous loads have been reported. Penalties rarely, if ever, approach the maximum.

\section{Canada Shipping Act ${ }^{26}$}

Marine transport of goods, although not a vital concern in Alberta, is nevertheless of paramount importance in the Canadian context. Largely as a result of the 1917 Halifax disaster, ${ }^{27}$ the shipping of hazardous goods by water has been regulated far longer than any other mode of transportation. In light of this, one would expect this Act to reflect a better understanding of the issues than other statutes. Nothing could be further from the truth. In fact, this Act adopts what is probably the narrowest approach to dangerous goods of all Canadian legislation. For example, the Act restricts its definition of dangerous goods to those which are "... liable to endanger the lives of the passengers or imperil the ship, and includes all substances determined by the Governor in Council . . . to be dangerous goods." 28 No mention is made of possible hazards to the environment, installations or people not on board the ship. One can think of several types of dangerous goods which are at least as hazardous to those away from the vessel as to those on board the ship. High explosives and poisonous chemicals come immediately to mind. In view of the high toll of lives lost in Halifax in 1917, one finds this lack of concern shocking.

Section 450(5) of the Act allows the captain of any vessel improperly transporting dangerous goods to throw them overboard without fear of any civil or criminal responsibility or liability. Arguably, such extensive authority should be strictly curtailed, limited to instances where the captain has reasonable and probable grounds to believe that the ship and/or people on board are in immediate danger. Unwarranted release of cargoes should render those in control liable for any ensuing harm.

22. Supran. 18.

23. C.R.C. vI, c. 2.

24. Supran. 18, s. 6(4).

25. R. v. Reid(1979) 19 Nfld. \& P.E.I.R. 520 (Nlfd. S.C.C.A.) Supra n. 21.

27. A freighter laden with munitions blew up in Halifax harbour, creating the largest man made non-nuclear explosion in history. Hundreds were killed or injured.

28. Supran. 21, s. 2. 
Section 450(8) of the Act stipulates that a prosecution for a breach of its provisions or of the Dangerous Goods Shipping Regulations ${ }^{29}$ can only be commenced with the consent of the Minister of Transport. Upon conviction, fines can range from $\$ 50$ to $\$ 1,000 .^{30}$ As well, the Admiralty Court has authority to order the seizure and forfeiture of improperly shipped dangerous cargoes. ${ }^{31}$ There are no reported instances of this power having been exercised. It should be noted that these provisions apply only to ships registered in Canada. The percentage of marine transport of hazardous materials in Canadian waters on non-Canadian registered ships is unknown.

Although there are major weaknesses in the Act, these are for the most part counterbalanced by the strengths of the Regulations. These regulations are consistent with international standards. ${ }^{32}$ Twelve major classes of goods are covered: explosives, compressed gasses, corrosives, poisons, flammable vapours, water-reactives, supporters of combustion, readily combustable materials, those reactive with air, laboratory and medical supplies, those carried in barges and other unmanned vessels, and all others. ${ }^{33}$ This comprehensive categorization of substances contemplates the protection from harm to the environment as well as to the ship itself.

\section{Railway Act ${ }^{34}$}

Under section 296(1) of this Act, the CTC has the explicit authority to regulate the rail transport of dangerous goods. It has done so by enacting a series of regulations and CTC orders, compiling these into the so-called "Red Book" of rail safety. ${ }^{35}$ This "Red Book" is based on its American counterpart, promulgated by the United States Department of Transport. ${ }^{36}$

Due to the significant volumes of transport between Canada and the U.S.A., similar standards are necessary to promote both safety and transport efficiency. Differences have arisen, however, largely as a result of CTC improvements to the "Red Book" system. The major modification implemented by the CTC is that of the placard system. ${ }^{37}$ All dangerous goods transported by rail must be accompanied by an approved placard securely attached to the outside of the rail car. The colourcoded cards indicate the type of substance carried, the hazard posed and the severity of the risk. As well, a manifest of dangerous goods is to be kept on hand by the train crew at all times. ${ }^{38}$ The manifest expands upon the information listed on the placards and contains more specific data

\footnotetext{
29. C.R.C. $v X V$, c. 1419 as am. SOR/81 951 .

30. Supra n. 21, s. 450(7).

31. Id. at s. 451 .

32. See Shaw, Savill \& Albion Co Ltd. v. The Electric Reduction Co. [1955] 3 D.L.R. 617 (Que. S.C.).

33. Supra n. 29.

34. Supra n. 17.

35. Canadian Transport Commission, Regulation for the Transportation of Dangerous Commodities by Rail.

36. Title 49, U.S. Code of Federal Regulations.

37. Grange J., Report of the Mississauga Railway Accident Inquiry(1980) at 121.

38. Id. at 113 .
} 
such as the location of the load on the train, those to contact in case of emergency, and the appropriate action to take should problems arise. Finally, the CTC has established criteria for the marshalling of rail cars which are designed to ensure that dangerous goods cars are well segregated from crew areas and from potentially explosive loads. These measures are intended to increase the chances of crew survival in the event of a major explosion. However, according to Mr. Justice Grange, had the derailed cars in the 1979 Mississauga train derailment been properly segregated, thousands of lives may have been lost. ${ }^{39}$ Apparently, propane explosions forced the leaking chlorine high into the atmosphere where it could disperse relatively safely. Had the propane cars been further away from the chlorine, it could have remained at ground level, perhaps killing or injuring thousands. The dilemma possibly posed by conflicting safety criteria, one to promote crew survival, and the other to protect the public, has not been fully resolved by the CTC. ${ }^{40}$

Largely as a result of the Mississauga train derailment, the CTC, in conjunction with its American counterpart, instituted plans to increase the safety of rail transportation through the use of better rail cars. ${ }^{41}$ Regulations and orders increasing safety criteria have become commonplace. ${ }^{42}$

\section{Environmental Contaminants Act ${ }^{43}$}

This Act is designed to deal with commercial manufacturing or processing activities which may result in the emission of a wide range of pollutants. Aside from prohibiting the release of specified chemicals beyond set limits, the Act empowers Environment Canada of ficials to research and collect data on suspected pollutants. To date, the Environmental Contaminants Act has been utilized only to prohibit or restrict PCB's, Mirex and related substances. ${ }^{44}$ It has not specifically been applied to transport-related issues and it does not seem likely that it will be so used.

\section{Hazardous Products Act ${ }^{45}$}

The Hazardous Products Act, administered by Consumer and Corporate Affairs, is primarily a consumer protection statute, controlling the importation, sale and advertising of a wide range of products ranging from electrically conductive kite string to the most highly toxic industrial chemicals. Since under this Act the importation of scheduled substances can be restricted or banned, there is potential for the Act to have an indirect impact on international transportation. However, should Consumer and Corporate Affairs attempt to do so, a conflict could arise between that department and Transport Canada. Accordingly, there is little, if any, likelihood of this Act being so used at this stage.

39. Id. at 150.

40. Supran. 8.

41. Id. at 54-56.

42. Id..

43. S.C. 1974-75-76, c. 72.

44. C.R.C. $v V$, c. 564 as am.

45. R.S.C. 1970 , c. H-3. 


\section{National Transportation Act ${ }^{46}$}

Section 36 of this Act specifically empowers Transport Canada to preempt existing authority delegated to provinces over extra-provincial motor transport (as delegated under the Motor Vehicle Transport Act). ${ }^{47}$ This provision has never been used. However, its existence alone can be seen as one factor in maintaining a high level of co-operation between federal and assorted provincial transport officials.

One would imagine that if informal federal-provincial agreements on extra-provincial transport do not work out as well as anticipated, section 36 could be utilized to force the issue. It is partly for this reason that new Alberta legislation clearly allows for Edmonton-Ottawa agreements on dangerous goods transport. ${ }^{48}$ Ontario and Prince Edward Island have followed suit. ${ }^{49}$ Other provinces are still drafting their relevant statutes. ${ }^{50}$

7. Pest Control Products Act ${ }^{51}$

The application of this Act is similar to that of the Hazardous Products Act, with the exception that it deals solely with pesticides, herbicides and fungicides. The importation of these products can be restricted or prohibited. Pest control products posing unique hazards may be required to meet special labelling and packaging criteria during transportation in bulk. ${ }^{52}$ As yet, this stipulation has been limited to the placing of warning signs on the chemicals' containers. Of course, the regulations of general application must also be complied with.

While the above noted statutes do have an ancillary relationship to hazardous material transportation, on the whole, the powers conferred thereunder are not used. All dangerous goods transportation regulation is essentially under the mandate of the CTC.

C. PROVINCIAL - ALBERTA

1. Motor Transport Act ${ }^{53}$

In Alberta, almost all aspects of transport regulation are under the ambit of the Alberta Motor Transport Board, established by the Motor Transport Act. The Board has wide regulatory powers to enter reciprocal agreements with other provinces and the federal government and to control equipment, usage and insurance of motor transport companies. Additional powers enable the Board to regulate the number of transporters operating in the province. To date, this power has only been used with

46. Supran. 16.

47. R.S.C. 1970 , c. M-14.

48. Transportation of Dangerous Goods Control Act Alberta Bill 8, 19 Leg 4 Sess. s15 Royal Assent Granted 4 May 1982.

49. Dangerous Goods Transportation Act S.O. 1981, c. 69, s. 12. Dangerous Goods (Transportation) Act S.P.E.1. 1981, c. 9, s. 14.

50. Discussion with the Hon. Jay Cowan, Minister of Environment and Northern Affairs, Manitoba 4 June 1982.

51. R.S.C. 1970 , c. P-10.

52. Id. s. 4.

53. R.S.A. 1980 , c. M-20.

54. Canadian Transport Commission, The Alberta Trucking Industry 1. 
respect to extra-provincial carriers. ${ }^{54}$ It is conceivable that these powers could be used to establish specific criteria for dangerous goods carriers, but little has yet been done.

The Bills of Lading and Conditions of Carriage Order ${ }^{56}$ promulgated under this Act has codified the common law liability of non-private carriers. ${ }^{56}$ Unless a carrier is made aware of the nature of the goods transported, he is under no duty to take more than normal care of them. A carrier will not be held liable for damage caused by dangerous goods unless he was aware of what was being transported and failed to take diligent precautions.

All articles shipped must be packaged to the carrier's satisfaction and be in a state which renders them safe for transportation. The carrier has the right to refuse to transport unsafe goods. The carrier, in the absence of an express agreement to the contrary, cannot be made liable to the shipper for a "defect or inherent vice in the goods" ${ }^{57}$

The General Regulations ${ }^{58}$ under the Act control vehicles carrying such products as explosives, flammable liquids and compressed gases. Further provisions exist for garbage trucks. No exact definition is given for "garbage truck", but presumably it could include vehicles designed to transport special industrial wastes as well as the more familiar municipal wastes.

\section{Motor Vehicle Administration Act 59}

This Act governs the licencing of both vehicles and drivers. Specific allowance is made for different classes of each. Drivers are licenced according to the type of vehicle driven with different medical and training requirements mandated for each class of licence. With such a scheme fully operational already, it would be a relatively simple matter to add yet another class of licence for the dangerous goods transporter. A person handling special cargoes should be quite familiar with the nature of the loads carried and should be trained to react properly in the event of an emergency.

Similar provisions and differentiations are made for vehicles. Trucks are classified to some extent according to weight and use. Section 37 of the Act empowers the Minister of Transport to regulate highway trailers on the basis of "carrying capacity, construction, use or any other circumstance." Standards have been set for some specified vehicles under this Act, the Motor Transport Act ${ }^{60}$ and the Boilers and Pressure Vessels Act. ${ }^{61}$ Given the wide powers available to the Minister, it would be a relatively simple matter to expand the regulations to include all vehicles transporting hazardous cargoes.

55. Alta Reg $452 / 78$ as am. $98 / 80$.

56. A private carrier operates his own fleet for transporting only his own goods. A common carrier is in the business of transporting goods for others.

57. Supran. 55, s. 14(1).

58. Alta Reg 69/57 as am s. 3.5 .

59. R.S.A. 1980 , c. M-22.

60. Supran. 53.

61. R.S.A. 1980 , c. B-8. 


\section{Agricultural Chemicals Act ${ }^{62}$}

Like the Boilers and Pressure Vessels Act and the Hazardous Chemicals Act, ${ }^{63}$ this Act deals with special use cargoes and with transportation in general, in an oblique manner. The Agricultural Chemicals Act deals directly with pest control products, as defined under the accompanying federal legislation, ${ }^{64}$ and with fertilizers. The Pesticide Sales, Use and Handling Regulations ${ }^{65}$ under this Act stipulate that when pest control products are transported, they must be clearly labelled and segregated from other goods, especially food and drink. Under section 17 of the Act, the unsafe transportation of these chemicals can be halted for up to seven days by Ministerial order. This power has apparently never been used.

\section{Hazardous Chemicals Act ${ }^{66}$}

This Act, for a multitude of reasons, is useless in practice. Under section 4(4), the Minister of the Environment may demand specific information relating to hazardous chemicals, including details on how to deal with the chemicals if they are released into the environment. As far as can be ascertained, this power has yet to be used. Even if it were to be exercised, it is possible that upon court challenge, section 4(4) would be ruled ultra vires the province, as it may impinge upon federal copyright and patent secrecy laws. ${ }^{67}$ The problem of confidentiality of industrial information is not well addressed in this statute.

The Director of Pollution Control, by virtue of section 6(1) of the Act, has the authority to issue control orders to deal with specific pollution problems, presumably including those related to transportation. Again, it appears this power has never been utilized in the transportation sector.

It is interesting to note that although this Act was passed by the Legislature in 1978 with great fanfare and with much ado about impending strict enforcement, it has never been used. To date, the government has not even passed regulations under the Act determining to which chemicals it is to apply.

With the foregoing in mind, one can only hope that the 1982 amendments to the Act, assented to May 4, 1982, will not suffer the same fate. ${ }^{68}$ The recently enacted sections 7.3 and 7.4 establish a mandatory manifest system for all hazardous chemical transport in the province, and direct that any transport, storage or disposal of these substances comply with the provisions of the Clean Air Act, ${ }^{69}$ Clean Water Act ${ }^{70}$ and other relevant statutes. As yet, no regulations detailing the operations of these sec-
62. R.S.A. 1980 , c. A-6.
63. R.S.A. 1980 , c. H-3.
64. Supran. 51.
65. Alta Reg 213/80.
66. Supran. 63.
67. See Copyright Act R.S.C. 1970, c. C-30.
68. Hazardous Chemicals Amendment Act Alta Bill 16, 19 Leg 4 Sess. Royal Assent Granted 4 May 1982.
69. R.S.A. 1980 , c. C-12.
70. R.S.A. 1980 , c. C-13. 
tions have come forth. It does appear that the regulations, when prepared, will act in concert with the new Transportation of Dangerous Goods Act, discussed infra. ${ }^{71}$

\section{MUNICIPAL}

Several municipalities in Alberta have enacted by-laws establishing truck routes, of ten with restricted transportation corridors for dangerous cargoes. Under both Calgary By-law 77/75 and Edmonton By-law 6219,72 the transportation of dangerous goods is restricted to specified transportation areas, normally isolated from predominantly residential neighbourhoods. Unless making a delivery of a dangerous cargo within the city, the carrier must take the shortest designated route possible. ${ }^{73}$ Dangerous goods vehicles are banned from the central business areas of the cities from 6:00 a.m. to 6:00 p.m., except when making deliveries to the area. ${ }^{74}$ In Calgary, "pup" trailers containing hazardous materials are prohibited from entering the central business district. ${ }^{75}$

Before extremely flammable cargoes are permitted to travel within either city, advance notice must be given to the city Fire Marshall and/or Traffic Commissioner for approval. ${ }^{76}$ Trucks carrying dangerous loads are also limited in where they can park or be stored overnight. ${ }^{77}$ Failure to comply with the ordinances may result in fines of up to $\$ 500$ or 60 -day jail terms. ${ }^{78}$

A major weakness common to both by-laws is that they deal only with dangerous goods above certain weights. The Calgary by-law exempts loads under $1,000 \mathrm{~kg}$. and the Edmonton by-law does not apply to any goods of less than $250 \mathrm{~kg} .{ }^{79}$ Neither of these arbitrary figures reflects the fact that among dangerous goods, some are inherently much more hazardous than others. For example, the spill of $1,000 \mathrm{~kg}$. of gasoline, serious enough as it is, would not be as potentially dangerous as the release of even one kilogram of dioxin. Perhaps some sort of "sliding scale" is called for, with different classes of goods being separately regulated.

A problem not apparent on the face of either by-law is that neither city has an adequate road by-pass system. In both cities, the lack of proper transportation corridors necessitates dangerous goods routes coming un-

71. See discussion on Recent Canadian Legislation, infra.

72. As am. This by-law amends Edmonton's Traffic Bylaw \#5590.

73. Calgary By-law 77/75, s. 5C.

Edmonton By-law 5590, s. 815(2)

74. Calgary By-law $77 / 75$, s. SB

Edmonton By-law 5590, s. 815(6). Note: In the Edmonton by-law, this section applies seven days per week, while the Calgary provision is effective only Mondays through Saturdays.

75. Calgary By-law 77/75, s. 5D.

76. Calgary, s. SG.

Edmonton, s. 815(3), (4)(c). (6)(c).

77. Calgary, s. 5A, s. SE(b).

Edmonton, s. 815(1)(g), s. 815(5)(a)

78. Calgary s. 17A.

Edmonton, Schedule IV, Schedule of Fines, Special Classes of Vehicles, Part 8.

79. Calgary, s. 5A(a)(1).

Edmonton s. 815(4)(a), as am. by By-law 6603. 
comfortably close to both residential areas and water supply systems. ${ }^{80}$ Short of a major revamping of urban transportation, little can be done to correct this problem.

It appears that these are the only two cities in the province with special provisions for dangerous cargoes. Neither Red Deer nor Medicine Hat has similar stipulations in their truck routes by-laws. Hanna, which may become the site of a special waste management treatment/disposal plant, is contemplating the enactment of such an ordinance.

Once the new provincial Transportation of Dangerous Goods Control Act ${ }^{81}$ is fully implemented, all municipal by-laws dealing with this subject will become inoperative unless approved by the provincial Minister of Transport. ${ }^{82}$

No specific data is available on compliance with these by-laws. Given that voluntary payment tickets can be issued in lieu of summons, the number of violations is not readily ascertainable. No reported decisions on the by-laws have been located. However, indications are that some enforcement does take place and that those ticketed normally pay the stipulated fines.

\section{PROBLEMS}

\section{A. JURISDICTION}

The Canadian constitutional system has created a split in powers between the federal and provincial governments over the transportation sector. ${ }^{83}$ The federal government has exclusive jurisdiction over aviation, shipping, most railways, trade and commerce, matters of national concern and works and undertakings declared to be for the benefit of Canada. ${ }^{84}$ The provincial domain is restricted to control over intraprovincial matters excluded from federal control. Relevant powers include property rights within the province, licencing of trades and powers of taxation. ${ }^{85}$ Some specific concerns may be delegated by the provinces to local municipalities, enabling them to establish local truck route bylaws and to deal with limited aspects of transportation safety. ${ }^{86}$

In the area of inter-provincial motor transport, the federal Motor Vehicle Transport $\mathrm{Act}^{87}$ delegates to provincial authorities licencing and regulatory powers over the industry as if it were entirely an intraprovincial matter. To date, the Alberta Motor Transport Board which administers these powers in the province, has been primarily concerned

80. In Calgary, routes such as the Bow Trail and Glenmore Trail pass through major commercial and residential areas. Edmonton's use of the Whitemud Freeway as a Dangerous Goods Route has caused concerns with citizens in the vicinity.

Calgary's Glenmore Trail passes over the Glenmore Reservoir, source of 2/3 of Calgary's water supply. A major spill on the causeway could destroy or impair the city's capability to supply suitable drinking water.

81. Alta. Bill 819 Leg, 4 Sess. 1982, 31 Eliz II, to come into force on proclamation.

82. Id. at s. 17.

83. See Appendix.

84. Constitution Act, 1867 s. 91.

85. Id. at s. 92.

86. Municipal Government Act R.S.A. 1980, c. M-26, S. 235.

87. R.S.C. 1970 , c. M-14. 
with economic regulation of extra-provincial motor transport. Both the number of carriers allowed to operate and the tariffs charged are tightly controlled. Little effort has been made to regulate other aspects of the industry, such as extra-provincial motor transport of dangerous goods. ${ }^{88}$ Even less authority is exerted over the intra-provincial trucking industry. ${ }^{89}$

Although it would seem that this wide grant of powers to provincial authorities would give rise to a disparity of regulation amongst the provinces, two factors tend to maintain equilibrium: economic realities and the threat of federal intervention. From an economic viewpoint, it is essential that all jurisdictions co-operate in order to promote the efficient flow of goods. The costs of re-routing shipments around recalcitrant provinces or of repackaging goods to allow transportation within a particular province would be exorbitant so as to prevent viable trade. It is clearly within the interests of all involved to maintain a high degree of uniformity for extra-provincial transport, while allowing some flexibility to ensure safety in local instances.

The dangers of the more reluctant provinces enacting only minimal standards of regulations have been largely avoided by the fact that the federal government can easily remove from the provinces the powers delegated to them under the Motor Vehicle Transportation Act. Section 36 of the National Transportation Act enables the federal government to withdraw from the provinces the powers delegated to regulate extraprovincial motor transport and revest this authority in the CTC. While prima facie this threat of removal of power may seem to promote interprovincial co-operation with Ottawa on issues related to extra-provincial transport, in reality it is merely a paper threat. Given the current realities of politics between the federal and provincial governments, the exercise of such a provision would be no less than ludicrous. Provinces would not readily give up powers used by them for the past thirty years.

Although there has been an informal consistency of regulation amongst the provinces, local conditions and changing situations have created some disparities. Not surprisingly, some of these incongruities have arisen in related legislation, such as the transport requirements for pesticides found in the Alberta Agricultural Chemicals Act and Regulations. ${ }^{90}$ Other dissimilarities are apparent in regulations concerned with specific types of goods transported, most notably dangerous goods. For example, for years Ontario has explicitly regulated the transportation of specified petroleum products under the Gasoline Handling Act. ${ }^{91}$ Under the Act and related regulations, an extensive code of petroleum handling control has been formulated. This scheme has had only minimal impact on extra-provincial transport of these substances, as the vast majority of such transport is within the province. This Act has been enforced since

88. Ellison, T. D. "The Proposed Federal Act and Regulations for the Transport of Dangerous Goods" presented to Symposium on the Transportation of Hazardous Materials III-B-2.

89. Supra n. 2 at 1.

90. Supran. 62.

91. R.S.O. 1980 , c. 185. 
the 1930's and is likely to remain in effect until the implementation of a uniform national code under the Transportation of Dangerous Goods Act $^{92}$ and its companion provincial Act which should take place some time this year.

Another form of jurisdictional split can arise within a given level of government between assorted departments and agencies. A classic Canadian example of this jurisdictional dichotomy is found in the federal regulation of pest control products. Environment Canada has always contended that these substances are of sufficient environmental concern to warrant their control. Recent studies have supported this position. ${ }^{93}$ However, the Department of Agriculture was granted authority because these chemicals are used primarily for agricultural purposes.

It is conceivable that a similar conflict could arise in the transportation sector, especially with regard to dangerous cargoes. In the event of transport related spills of a hazardous nature, it is logical that both transport and environment of ficials be notified. New legislation dealing specifically with dangerous goods transportation could equally be considered environmental law or transport law. This duality of character has caused some confusion and discussion over exactly who is to enforce the law. For example, according to the Honourable J. Cowan, Manitoba Minister for Environment and Northern Affairs, Manitoba's new transportation of dangerous goods law when passed, should be under the control of his department, as it is primarily aimed at prevention of environmental harm. However, according to Mr. J. Kingham of Environment Canada, "the control of hazardous waste transportation per se is more appropriate to the Department of Transport." 94 It seems likely that for the most part, transport of ficials will oversee the new legislation, with Environment personnel being involved only in the cleaning up of spills. Transport Canada has for years maintained a special Transportation of Dangerous Goods Branch which acts as a liaison and co-ordination service in the maze of relevant bureaucracy, and drafts the new regulations concerning dangerous goods transport. ${ }^{95}$

\section{B. ENFORCEMENT}

Even with the most comprehensive legislation, regulation of any industry is impossible without viable enforcement. Unfortunately, enforcement of transportation safety legislation is lax.

The 1979 Mississauga train derailment which resulted in the evacuation of 250,000 people because of leaking chlorine and propane, focused public attention on practices in the transportation of dangerous goods. After the accident, the federal government requested an inquiry which

92. Supra n. 13. Section 32(1)(a) came into force as of November 1, 1980.

93. Hall, R. "A New Approach to Pest Control in Canada", Report \#10 of Canadian Environmental Advisory Council. July 1981.

94. Kingham, J. D. "Activities of Environment Canada Relative to Environmentally Hazardous Materials" presented to the Symposium on the Transportation of Hazardous Materials III-C-10.

95. Ellison, T. D. "Regulation Making Under the Transportation of Dangerous Goods Act" presented to Roundtable Discussion on Toxic Chemicals Law and Policy in Canada, 4. 
was held by Mr. Justice Grange. The ensuing Report of the Mississauga Railway Accident Inquiry ${ }^{96}$ contained several findings of major importance. It was noted by the inquiry that although property damage in the accident exceeded several millions of dollars, prosecutions under the Railway $\mathrm{Act}^{97}$ could only result in a maximum $\$ 500$ fine. ${ }^{98}$ There have been no prosecutions under the Act since at least 1967.99 After the Mississauga accident, railway inspectors conducted a series of spot checks on railway equipment, apparently for the first time in years. Twenty-seven percent of inspected cars had reportable defects. ${ }^{100}$ The Commission of Inquiry heard much evidence suggesting that rail crews consistently ignored safety regulations concerning rail car inspection procedures and marshalling of trains. ${ }^{101}$ It is to be noted that the train that derailed in Mississauga was not operating in compliance with several safety regulations. ${ }^{102}$

Since the release of the Grange Report, the CTC has instituted major changes in both its regulatory and enforcement operations. ${ }^{103}$

The lack of serious enforcement of the provisions of the Railway Act noted by Mr. Justice Grange may reflect a long-standing reluctance to prosecute. Although there have been prosecutions for improper transportation of dangerous goods, notable exceptions are also reported. $R$. v. Michigan Central Railway ${ }^{104}$ is one of the most significant instances of a failure to prosecute under the Railway Act. The railway negligently transported a cargo of dynamite; an explosion killing two and injuring forty resulted. The Board of Railway Commissioners (predecessor to the CTC) refused to prosecute. (Even if they had, the maximum fine under the Railway Act was only $\$ 500.00$.) Instead, a grand jury preferred an indictment against the railway, charging it under the Criminal Code with nuisance and carrying dangerous explosives without proper precautions. The first charge was withdrawn after the company plead guilty to the second. Upon conviction, rather than the $\$ 500.00$ fine allowable under the Railway Act, the defendant was fined $\$ 25,000.00$, no small amount in 1907.

The circumstances surrounding this case raise several interesting issues. Why did the Board of Railway Commissioners refuse to prosecute? Why are the penalties under the Act minimal at best? Should the Criminal Code be utilized more of ten in these cases? It is not suggested that what occurred in 1907 is of great practical use today, yet one must wonder why the CTC still lacks the control over the railways' handling of dangerous cargoes.

\footnotetext{
96. Supran. 37.

97. Supra n. 17 at s. 385 .

98. Supra n. 37 at 3.

99. Id. at 191.

100. Id. at 122-23.

101. Id. at 20-24.

102. Id..

103. Supran. 40.

104. (1907) 10 O.W.R. 660 .
} 
If regulation of the railway industry can be said to be sporadic, enforcement of regulations concerning air transport must be considered non-existent. The recent Royal Commission on Aviation Safety ${ }^{105}$ under Mr. Justice Dubin heard considerable evidence that small air carriers virtually ignore all safety directives. ${ }^{106}$ With only fifteen air enforcement specialists across the country to check on over 20,000 aircraft, it is not surprising that enforcement is weak. ${ }^{107}$

Although penalties for breaching the Aeronautics Act ${ }^{108}$ can reach up to $\$ 5,000.00$, the CTC apparently prefers to deal with infractions by negotiation or by threats of suspension or revocation of operating licences. Rarely are licences actually suspended and it is almost unheard of for them to be revoked. Political pressure on enforcement personnel is well accepted as the major reason for this lack of activity. In one major case, a threatened licence suspension was not finalized because of potential "embarassment to the Minister [of Transport]". ${ }^{109}$ On the rare occasions that violations of the Act resulted in prosecution, the average fines imposed were low; in 1978, the average fine was only $\$ 165.00 .{ }^{110}$

The Royal Commission did not have a specific mandate to investigate procedures for transporting dangerous goods by air. However, several disturbing facts on the general topic came to light. The air freight industry annually transports 500,000 tons of goods, with a $9.5 \%$ growth rate. ${ }^{111}$ The proportion of dangerous goods flown is unknown, but can be estimated at about $10 \% .{ }^{112}$ Most of these goods are transported into remote, northern areas which may be especially sensitive to environmental degradation should a spill occur. Yet few people in the industry are even aware of what they transport as cargo or know how to safely handle these items. A 1981 safety audit of Transport Canada's Air Transport Administration fleet revealed a serious lack of dangerous cargo handling training. ${ }^{113}$

Provincial controls in other areas of transportation are not enforced any more stringently. A study of the Alberta trucking industry commissioned by the CTC showed that the Alberta Motor Transport Board maintained a policy of minimal interference in intra-provincial trucking. ${ }^{114}$ Extra-provincial transporters were controlled by limiting entry to the industry to those who could demonstrate financial stability and a need for the proposed services.

Enforcement of technical and safety standards is split between Alberta Motor Transport, Boilers and Pressure Vessels Inspectors and police

105. Dubin, J., Report of the Commission of Inquiry on Aviation Safety (1981).

106. Id. at 293.

107. Id. at 291.

108. Supra n. 18.

109. Supran. 105 at 25.

110. Id. at 339.

111. Id. at 12.

112. This would be consistent with estimates of dangerous goods cargo proportions carried by other modes of transport.

113. Supran. 105 at 620.

114. Supran. 2 at 1. 
forces. Although there is a strong degree of informal co-operation between these groups, a more consistent manner of enforcement would be desirable.

Another factor tending to weaken enforcement levels is lack of proper funding for personnel. Without highly trained staff in sufficient numbers to enforce regulations, voluntary compliance will have to be relied on. Statistics indicate that voluntary compliance is equivalent to no compliance.

\section{CARRIERS' LIABILITY}

The present regime of compensating victims of pollution is a patchwork quilt of common law causes of action (torts), private insurance, voluntary programs established by high risk industries and a variety of statutory schemes, each limited to a narrow subject matter. ${ }^{118}$

Until the early years of the twentieth century, the liability of carriers for the goods transported was at common law akin to that of an insurer. ${ }^{116}$ However, most carriers had established contractual means of limiting their liabilities through the use of exclusion clauses and other conditions in the bills of lading. ${ }^{117}$ In order to prevent excessive use of these devices and at the same time protect carriers' interests, several statutes and treaties were implemented to delineate exactly the extent and scope of carriers' liability. International treaties such as the Warsaw Convention dealing with aviation and The Hague Treaty on shipping ensured consistency among signatory states.

In Canada, the Carriage of Goods by Water Act ${ }^{118}$ and the Carriage by Air Act ${ }^{119}$ recognize these international obligations. The Railway Act ${ }^{120}$ provides for similar limitations upon Canadian rail carriers.

The Nuclear Liability Act ${ }^{121}$ establishes absolute liability for specified modes of handling radioactive materials. The operator of a nuclear facility under section 3 of the Act is deemed absolutely liable for all harm caused in the transportation of radioactive substances from outside Canada to the licenced facility. If necessary, up to seventy-five million dollars is available for compensation purposes.122 In Alberta, the liability of carriers vis-à-vis shippers is limited by the Bills of Lading and Conditions of Carriage Order ${ }^{123}$ promulgated under the Motor Transport Act. ${ }^{124}$

While the provisions of these edicts have served carriers and shippers quite well, weaknesses do remain, especially in relation to dangerous goods transport. A carrier's liability for damages is only to the shipper of

115. Swaigen J. Compensation of Pollution Victims in Canada.

116. Great Northern Rlwyv. L.E.P. Transport [1922] 2 K. B. 742 (Eng. C.A.).

117. Id..

118. R.S.C. 1970 , c. C-15.

119. R.S.C. 1970, c. C-14.

120. Supra n. 17.

121. R.S.C. 1970 , c. 29 (1st Supp) proclaimed 11 Oct. 1976.

122. Supran. 115 at 49.

123. Supran. 55.

124. Supra n. 53. 
the goods on the basis of breach of contractual obligations. Between carrier and shipper, damages can be calculated and awarded fairly quickly. Should an innocent third party be injured as a result of a carriage-related accident, relief must be obtained through the tedious process of civil litigation. Normally, a potential plaintiff must be able to show, on the balance of probabilities, that the carrier or shipper was negligent in allowing the accident to occur and that the resulting injury was forseeable. This can pose tremendous problems. It is currently estimated that the average civil suit which goes to trial requires over two years from the time of the incident to final resolution. This contrasts sharply with the months or even weeks normally required to resolve carrier-shipper disputes. ${ }^{125}$

An alternative to common law remedies and legislated liability is the use of insurance systems, either on a voluntary or regulated basis. In Canada, a corporate insuree can obtain an Environmental Liability Package which is designed to provide for funds in the event of pollution damages. The standard package apparently does not cover transportation risks. ${ }^{128}$ There is insurance available for dangerous goods transporters, but this is based not so much on the nature of the cargo carried, but on the mode of transportation used. ${ }^{127}$

Mandatory insurance requirements are common for vehicles; in Alberta, it is necessary to show proof of a minimum coverage of one hundred thousand dollars. ${ }^{128}$ In the United States, it is now mandatory for carriers of extremely dangerous goods to be insured for up to five million dollars. ${ }^{129}$ A similar approach could be adopted in Canada.

Another alternative is joint government-industry insurance. Under such a system, funds from both industry and the regulators would be pooled to provide compensation to those adversely affected by spills. This is the approach adopted under the Nuclear Liability Act. ${ }^{130}$ Ontario, in a recent amendment to Part IX of the Environment Protection Act ${ }^{131}$ (the so-called "Spills Bill" amendment) created the Environmental Compensation Corporation, which is to be funded by both government and hazardous waste handlers. These funds are to be used should compensation become necessary. Federally, there is as yet no statutory regime to deal directly with the compensation of those suffering damages as a result of dangerous goods transportation. Apparently, industry pressure forced the removal of such a system from the Transportation of Dangerous Goods Act when it was before Parliament. ${ }^{132}$

125. In many juridictions, carrier-shipper disputes are settled through negotiation and/or arbitration.

126. Supran. 115 at 39.

127. Despard, A.W. "Liability Insurance in Transportation" presented to Symposium on the Transportation of Hazardous Materials" III-E-1.

128. Supra n. 59 at ss. 60-69.

129. Motor Carrier Act, 1980, 49 U.S.C. \$10927, s. 30(2).

130. R.S. 1970 , c. 29 (1st Supp.).

131. R.S.O. 1980, c. 141, s. 99, as am.

132. Supran. 115 at 45. 
As a result of these problems, suggestions for reform have been proposed. It has been recommended by Mr. John Swaigen in a report to the Economic Council of Canada ${ }^{133}$ that because of the potential exhorbitant costs resulting from a dangerous goods accident, carriers of these goods should be required to meet special insurance standards or show other means of financial stability in the event of an accident. ${ }^{134}$ It has also been contended that carriers of dangerous goods should be strictly or absolutely liable to all those injured as a result of any event which occurs while the cargoes are in their care. ${ }^{135}$ These proposals, if implemented, would result in carriers once again being considered insurers of their cargoes, but now responsible to a wider group of potential claimants.

There is little doubt that holding carriers absolutely liable for the cargoes transported would change the industry dramatically. The question is, in what manner would the industry change? On the one hand, carriers could strengthen their safety procedures and increase their rates to financially compensate for the additional insurance costs. On the other hand, there is a distinct possibility that the incidence of "fly-by-night" operators, shady corporations which offer cut-rate services and declare bankruptcy the minute trouble appears, would increase.

A problem with strict liability plans, as with all compensation schemes, is that they adopt an after-the-fact approach to a serious problem. Preventative measures are desirable and necessary. It must be remembered, however, that it is impossible to totally eliminate the chances of a transport related spill; therefore, some form of compensation will always be necessary.

\section{AMERICAN LEGISLATION ${ }^{136}$}

Previous discussion has focused on the state of Canadian federal and provincial control of dangerous goods transportation. Several important weaknesses and limitations have been referred to. However awkward, the Canadian system does work reasonably well in comparison with its counterpart south of the border. Although many comparisons between Canadian and American regulatory schemes are unfair due to the different modes of government, the paramount importance of transportation between the countries and the fact that each is the other's largest trading partner warrant a brief look at the American system.

Primary responsibility for dangerous goods transportation regulation rests with the Department of Transport (DoT), which administers the Hazardous Materials Transportation Act ${ }^{137}$ and the 1980 Motor Carrier Act. ${ }^{138}$ Under the Hazardous Materials Transportation Act, technical safety standards regulate the containers used in dangerous goods

133. Id. at 16.

134. Supran. 3 at 345 .

135. Id. See also "Strict Liability for Generators, Transporters and Disposer of Hazardous Wastes" 64 Minn. L. Rev. 949.

136. For an excellent review of the American situation see Marten, supra n. 3.

137. 49 U.S.C. \$\$1801-1812 (1976 and Supp. III 1979).

138. 94 Stat. 793, Pub. L. No. 96-296 (1980). 
transport. These standards apply to about 1,200 listed hazardous chemicals. The Motor Carrier Act establishes minimum insurance criteria for transporters of hazardous materials. DoT jurisdiction is essentially inter-state; however, most intra-state statutes, because of their potential impact on inter-state commerce, act in accordance with federal regulations.

For some inexplicable reason, exclusive jurisdiction over the transportation of hazardous wastes has been granted to a different agency, the Environmental Protection Agency (EPA). ${ }^{139}$ One is hard pressed to imagine why this jurisdiction is so segregated. The EPA has implemented a wide range of regulations which require most hazardous waste shipments to be accompanied by detailed manifests. These must include such data as substance carried, emergency response information, shipper, carrier and destination. Regulations requiring the reporting of accidents have also been improved. ${ }^{140}$

In addition to this double jurisdiction over dangerous goods transportation, three other federal agencies maintain some jurisdiction over aspects of the industry. The Nuclear Regulatory Agency (NRA) shares authority with DoT over transportation of nuclear materials, with the NRA being responsible for highly radioactive materials and DoT for the less dangerous substances. The Occupational Health and Safety Administration (OHSA) regulates aspects of dangerous goods transport involving work protection. Finally, the Interstate Commerce Commission (ICC) has a general authority to regulate all aspects of interstate commerce.

Given the multitude of regulators of dangerous goods transport, conflicts are inevitable. EPA standards for hazardous wastes are not in accord with similar DoT criteria. ${ }^{141}$ Similar discrepancies exist between OHSA and DoT. The ICC appears to be the only agency which has deferred to DoT jurisdiction. ${ }^{142}$

Many of the problems faced by American regulators can be directly traced to the fact that there are too many agencies involved. In this regard, the American experience has been similar to that faced in Canada, but more intense. A significant difference between the American and Canadian approaches is that Canada is more active in attempting to rectify the problems of shared jurisdiction by means of comprehensive legislative reform. Reforms have been contemplated and it is anticipated that all agencies will eventually present a co-ordinated effort in the regulation of dangerous goods transport. However, such coordination is years behind schedule.

139. Resource Conservation and Recovery Act, 42 U.S.C.A. \$\$6901-6987 (West 1877 Supp. 1981).

140. Supra n. 3 at 352; supra n. 54.

141. Frye, R. S. "Recent Developments in the Transportation of Hazardous Materials" 10 Trans. L.J.97, 101.

142. Supran. 3 at 353. 


\section{RECENT CANADIAN LEGISLATION: THE TRANSPORTATION OF DANGEROUS GOODS ACT}

The current state of dangerous goods transport regulation is overly complex and fraught with practical difficulties. Passage of more stringent legislation in the United States and near-disasters such as the Mississauga incident have heightened awareness of the dangers involved in transporting these substances. The federal government responded by enacting the Transportation of Dangerous Goods Act (TDGA) in 1980. Alberta, Ontario and Prince Edward Island have followed suit. ${ }^{143}$ Manitoba and Saskatchewan are in the final stages of drafting their related statutes.

The TDGA contemplates an all-inclusive regulatory scheme for dangerous goods transport. The federal Act is to apply to all extraprovincial movements of these substances, as well as to all air, rail and non-bulk sea transport. ${ }^{144}$ The co-existent provincial statutes deal with intra-provincial vehicle transport. The federal statute, being the crux of the system, is worthy of the most detailed analysis. Other statutes will be considered where necessary, for comparison purposes.

The TDGA is designed to control all relevant aspects of the dangerous goods transport industry, except oil and gas pipelines, bulk sea transport and those items under the authority of the Minister of National Defence. ${ }^{145}$ In light of the need for cohesion and consistency, it is surprising to note how disjointed this integrated scheme of regulation is. The legislation in each jurisdiction should be compatible with its companion statutes, yet neither the Uniform Law Conference nor the Law Reform Commission of Canada has addressed their attention to these statutes. ${ }^{146}$

Because of a lack of co-ordination in the drafting of these statutes, significant differences exist. The major discrepancy is in the power to enter reciprocal agreements with other areas. Section 15 of Alberta's Transportation of Dangerous Goods Control Act allows the province to enter reciprocal agreements with both the federal government and other provinces. Ontario and Prince Edward Island both limit their agreement making powers to concords with Ottawa. ${ }^{147}$ The ramifications are not yet fully understood, nor is it ascertainable whether these dissimilarities will be done away with.

Ontario's Dangerous Goods Transportation Act shares with its federal counterpart a valuable provision which hopefully will be adopted by all other provinces. Section 12(3) of the Ontario Act and section 30 of the Federal Act require that an annual report on the administration and enforcement of the Act and regulations be prepared and distributed to the

143. Transportation of Dangerous Goods Contol Act, Alta Bill 8, 19 Leg., 4 Sess; Dangerous Goods Transporation Act, 1981, S.O. 1981, c. 69; Dangerous Goods (Transportation) Act, S.P.E.I. 1981, c. 9.

144. TDGA s. 3.

145. Id..

146. These comments are based on the most recent reports from these two organizations. However, in a letter circulated 28 Jan. 1982, the Law Reform Commission indicated that it wishes to look into the area of hazardous products safety regulation in general.

147. Supra n. 143, Ont. s. 12; P.E.I. s. 14. 
Legislature or Parliament, as the case may be. Public release of such data may be sufficient to help ensure that enforcement of ficials carry out their duties properly. Furthermore, the publication of this information will serve to educate the public in respect of the true dangerous goods transportation situation.

\section{A. PROVISIONS}

Under the Federal TDGA, the Minister of Transport is given the power to regulate the release of industrial information on products carried, packaging, handling, shipping, storage, delivery, bonding or other financial security arrangements, spill reporting and appropriate spill responses. ${ }^{148}$ Inspectors appointed under the Act are given powers to search, seize documents or goods, copy documents and refuse transport or entry to Canada of any dangerous goods shipped contrary to regulation. ${ }^{149}$ No prior court authorization is necessary for the utilization of these powers. Additionally, these inspectors are empowered to "request" that remedial action be taken by transporters to bring their loads up to acceptable standards prior to transport. ${ }^{150}$

In the event of a transport-related spill, there is a duty upon those present to immediately report the release and to take all appropriate emergency measures. ${ }^{151}$ If necessary, clean-up personnel can enter private land to carry out decontamination measures without warrants. Clean-up crews acting reasonably under the circumstances are protected from civil and criminal liability. ${ }^{152}$

While the preceding stipulations, if properly enforced, will increase the safety of the industry, significant weaknesses are inherent in the legislation. The definition of dangerous goods in section 2 is overly restrictive. Dangerous goods are those substances specified in the schedules or regulations under the Act. These are not yet compiled. By excluding a generic definition of dangerous goods ${ }^{153}$ and instead merely listing prescribed substances the Act may be less effective and comprehensive. Although every assurance has been made that the impending schedules will be all-encompassing, ${ }^{154}$ this legislative technique lends itself to regulations being implemented on political rather than scientific grounds. The concern is that the TDGA will be very selectively used, as is the Federal Environmental Contaminants Act. ${ }^{155}$ Those substances not listed will not be controlled.

The definition of "container" under the TDGA reads: 156

an article of transport equipment, including one that is carried on a chassis, that is strong enough to be suitable for repeated use and is designed to facilitate the transportation of goods by one or more means of transport without intermediate reloading, but does not include a vehicle.

148. TDGA, ss. 17, 19, 23.

149. TDGA, ss. 14, 15, 17.

150. TDGA, s. 14(3).

151. TDGA, s. 17(1), (2).

152. TDGA, s. 17(4), (5).

153. See, for example, supran. 1.

154. Supran. 95 at 4.

155. Supran. 53.

156. TDGA, s. 2. 
This definition is flawed in that it deals only with those containers designed for or capable of repeated use. Many dangerous goods are transported in forty-five gallon steel drums designed for only one use. It is not known what percentage of containers fall into this classification, but it is probably a fairly significant figure. Given the use of "disposable" containers for dangerous goods transport, it seems sensible that they be made subject to some form of control.

Another weakness inherent in the TDGA is that the Act is applicable only to Canadian registered vessels and aircraft. ${ }^{157}$ Dangerous goods transportation by foreign carriers is beyond the ambit of the Act. Again, the proportion involved is unknown.

Section 8 of the TDGA allows a defence of "due diligence" to prosecutions under the Act. According to this section, "[n]o person is guilty of an offence under this Act if he establishes that he took all reasonable measures to comply with the Act and the regulations." This defence, recognized by the Supreme Court of Canada in R. v. Sault Ste. Marie, 158 is bound to pose an array of problems for enforcers of the Act. The adoption of the "reasonable measures" test introduces a negligence standard; unless non-compliance with the statute can clearly be construed as prima facie evidence of negligence, most Canadian courts may find themselves rather uncomfortable with this sort of provision. This approach is aided by section $18(2)$ of the TDGA which deems that failure to take reasonable measures to comply is tantamount to negligence or fault. ${ }^{159}$

Even if the difficulties of the due diligence defence can be resolved, the concept may be inappropriate in the field of dangerous goods transport. Arguably, absolute liability is required to ensure maximum compliance with the legislation, given the potential consequences of a spill. Perhaps a shipper or carrier should escape liability only when the Act and regulations were complied with to their fullest extent. If damage still occurs, weaknesses in the regulations may be the cause, and governments responsible should bear the burden of compensation.

Absolute liability has been imposed in oil spill regulations under the Canada Shipping Act. ${ }^{160}$ In a relevant 1972 case, $R$. v. The Vessel "Himmerland", Bennet, Prov. Ct. J. stated that: “. . . it is necessary that the Crown prove beyond a reasonable doubt that by act or omission the discharge emanated from the vessel . .."161 Wilfullness or negligence need not be shown. Subsequent cases have reinforced that these offences are of absolute liability. ${ }^{162}$ Similarly, provisions under the Aeronautics Act and its regulations have been held to be absolute liability of fences. ${ }^{163}$

Inspectors are given powers to act in situations where there are reasonable grounds to believe that a spill is imminent. While it is ad-

157. TDGA, s. 3(2).

158. [1978] 2 S.C.R. 1299.

159. Similar provisions are found in other areas of Canadian law. For example, see the Alberta Highway Traffic Act, R.S.A. 1980, c. H-7, s. 179.

160. Oil Pollution Prevention Regulations, C.R.C. v. XVI c. 1454.

161. (1973) 2 C.E.L.R. 17 (Ont. Prov. Ct.).

162. R.v. "The Allunga". [1977] 3 W.W.R. 673 (B.C.S.C.). 
mirable that inspectors be allowed to act as they see fit in potential emergency situations to prevent harm, one is disappointed to note that these powers are limited to instances in which the risk is "serious and imminent". ${ }^{164}$ Aside from problems in defining these terms in advance, in order that inspectors know beforehand whether they are even entitled to act, one wonders why this criteria was put in. Arguably, with any spill of a dangerous substance, one should take all necessary steps to reduce all adverse effects, not just those considered "serious and imminent".

In addition to powers granted to the inspectors, there is authority vested in the Minister to order the cessation or improvement of transportation to eradicate serious risks to health, property or environment. ${ }^{165}$ Such power, by implication, would be used only in the most dire circumstances and would be applied only to the most dangerous materials. If these powers are exercised prior to transport to ensure proper shipment, no problems should arise. However, should these provisions be used to halt a shipment during transport, three immediate problems are likely to occur. First, what does one do with such a cargo? Having been halted due to an extreme perceived danger, something must be done quickly to either neutralize the substance itself or to minimize the potential for damage should a spill occur. Either option could be fraught with difficulties. In some instances, improvements to the mode of transport may be required. Evacuations may also be necessary. Second, who is going to pay for the costs of these measures? The Act is explicit as to costs when inspectors act, ${ }^{166}$ but on the topic of the costs of Ministerial action, it is silent. While logically, a negligent or reckless carrier should bear the burden, one would hardly expect such a company to do so willingly. Finally, any action taken under these sections may be of questionable legality. While emergency powers to halt or modify activity on the spot could be viewed as a logical extension of authority under the Act, it might be viewed as bordering on the type of authority traditionally exercised by the courts. The distinction between administrative decision and judicial order is indeed fine and is the subject of ongoing litigation. ${ }^{167}$ Powers such as these lend themselves to question. Should these provisions ever be utilized, it is almost inevitable that they will be quickly challenged in the courts.

Upon conviction for a breach of the Act or regulations, goods may be forfeited to the Crown. ${ }^{168}$ Although this would have financial impact on an imprudent transporter, two problems remain. First, is this a suitable sanction against an offender? Although the forfeiture of dangerous

163. Supran. 25.

164. TDGA, s. 15(1).

165. TDGA, s. 28.

166. Section $18(1)$ authorizes recovery of costs incurred in enforcing the provisions of ss. 14(3), $15(2), 17$.

167. Guise v. Williston (1963) 41 W.W.R. 331 (B.C.C.A.); Nicholson v. Haldimand Norfolk Police Commr. [1979] I S.C.R. 311.

168. TDGA, s. 15(5). 
goods from a private carrier would directly affect the company responsible, such an act against a common carrier would be ineffective. ${ }^{169} \mathrm{~A}$ more effective remedy is the imposition of licence suspensions or revocations upon those violating the Act.

Anyone with a valid proprietary interest in the seized goods may apply for their return. ${ }^{170}$ One wonders who is being punished if the owner of the goods is the one who must apply for their return, when it is the carrier who is at fault. Arguably, the TDGA is not directed at punishing those who unfortunately hire less than prudent carriers for their goods. This provision, if enforced against common carriers, would literally make a shipper his "brother's keeper".

It is interesting to note that inquiries into the causes of releases of dangerous goods are within the discretionary powers of the Minister of Transport. ${ }^{171}$ Inquiries under other statutes which have similarly been at the whim of the government have shown themselves to be quite adequate. However, the mere fact that they are not required even when, for example, there is loss of life, damage over $X$ dollars or release of the most dangerous substances, casts a shadow over their effectiveness. Public inquiries into causes of accidents with the aim of preventing future incidents should not be political tools.

In the event of legislative incongruency, the TDGA is deemed under section 31 to take precedence over other statutes. Such a provision, given the all-encompassing nature of the Act, is essential if efficient administration of the Act is to be achieved.

Section 23 of the Act allows the Minister to require disclosure of any relevant information on specified chemicals. With the exception of information required for emergency response and information dealing with the general nature of the hazard posed by the substance, all data is to be kept confidential and privileged under the Act. While one can appreciate the need for protecting trade secrets, one must still question whether this section provides for the release of sufficient information under nonemergency circumstances to allow for adequate planning of emergency responses. It may suffice to provide data after a spill occurs, but planners would be much better prepared if they had all the details beforehand. A court challenge to the release of information obtained under this section would be anticipated. Hopefully, the data obtained will be made available for all emergency planners, not just those within the federal government.

Section 26 of the TDGA gives the Minister authority to promote research, publicity and co-operation on all aspects of dangerous goods transport, up to and including the international level. As considerable coordination already exists, these powers are certain to be widely utilized. On a national level, specific authority is granted to undertake publicity campaigns and to unify and codify the regulations under the Act into a form more readable by the public. While publicity alone does little to en-

169. Supran. 56.

170. TDGA, S. 16.

171. TDGA, s. 20(1). 
sure compliance with the Act, the potential for creating public awareness and concern for the issues through education is immense. An aware and concerned public can apply great pressure to companies to comply with the Act. In addition, nothing in the Act prevents private prosecutions; thus, major weaknesses found in predecessor legislation have been avoided. While it is not anticipated that the public will play an active role in enforcing the Act, the fact that there is an option to do so is of itself quite valuable. This is particularly the case when government authorities, for whatever reasons, relinquish the responsibility to take action.

International co-operation is further enhanced by section 27 of the TDGA, which allows for the issuance of equivalency permits. If a cargo from a foreign jurisdiction substantially meets or exceeds Canadian standards, it may be deemed to be shipped in compliance with the Act. ${ }^{172}$ While in principle this type of provision is necessary to facilitate continued international trade, the practicalities of implementation pose horrendous problems. Until the standards of other countries have been fully developed and meet the section 27 criteria, effective application of the provision would be all but impossible. Even after equivalency standards have been set, a problem would still remain in determining compliance by individual carriers. ${ }^{173}$ Training of qualified staff in adequate numbers would be prohibitively expensive. Given current budget restraints, it is highly unlikely that sufficient funds will be made available to implement this aspect of the TDGA program.

\section{B. IMPLEMENTATION}

The TDGA scheme is to be implemented on a province-by-province basis as necessary provincial agreements and related legislation come into effect. This gives the individual provinces time to draft suitable legislation and train personnel in dangerous goods transportation handling. The advantage of this system is that enforcement of the Act will begin when a viable infra-structure is in place to deal with it. A disadvantage is that implementation may be delayed in some portions of the country while other provinces move towards enactment. Should the implementation system work as contemplated, the TDGA will become operational within the next few years.

Should a province fail to enter into an agreement with Ottawa on dangerous goods transport, section 32 could be resorted to. If, after one year or other reasonable time limit, an agreement with a particular province has not been reached, the TDGA can be used to usurp provincial jurisdiction over dangerous goods transport. Such a move by Ottawa may not be well received, especially in this era of poor federal-provincial relations. As well, such action may be of dubious legality. While it is

172. This section is similar in tenor to provisions found in related statutes, such as the American Resource Recovery and Conservation Act, supra n. 139. See Zener, R.V., Guide to Federal Environmental Law 177,78.

173. There are two dangers inherent in the use of equivalancy standards. One is that a "lowest common denominator" standard will prevail. The other is that a foreign jurisdiction may encounter problems in establishing its own standards or testing procedures. Either problem can impair both transportation safety and viable international dangerous goods trade. 
abundantly clear that the TDGA is intra vires Parliament vis-à-vis interprovincial transport, one would seriously question the validity of an attempt to exert authority over the purely provincial matter of intraprovincial motor transport. The only possible grounds for federal intervention in provincial matters are: POGG (Peace, Order and Good Government), regulation of trade and commerce, criminal law, works or undertakings declared to be for the benefit of two or more of the provinces and residual powers to act in any field not occupied by provincial powers. ${ }^{174}$

POGG powers have traditionally been restricted by the courts to those issues meeting the test of "national concern". It will be difficult, however, to justify the TDGA scheme under this head of power, especially where traditional provincial rights are concerned. The use of legitimate federal powers to squeeze out provincial authority is poorly received by the judiciary.

It is unlikely that this Act will be construed as dealing with the regulation of trade and commerce. Normally, this power is reserved for extraprovincial undertakings. Previous federal attempts to control trade and commerce in this manner have been declared inoperative in no uncertain terms: ". . . the Parliament of Canada may not, in the guise of regulating trade and commerce, reach into the fields allocated to the provinces .. $\therefore 175$ Unless it is established that the regulation of intra-provincial transport is "necessarily incidental to" 176 extra-provincial trade and commerce, this head of federal power is unlikely to uphold the TDGA.

It has been established that a quasi-criminal statute dealing with environmental matters can be a valid exercise of federal jurisdiction in criminal law. ${ }^{177}$ However, the use of criminal powers to improperly usurp provincial powers is not tolerated. Another reason this legislation cannot be classified as criminal is that traditionally, criminal law powers have been viewed as prohibitory rather than regulatory. ${ }^{178}$ The TDGA makes no pretence about its aims; it is a statute designed to regulate an industry, not one prohibiting specified activity.

It is possible that by declaring all transportation of dangerous goods to be a work or undertaking for the benefit of two or more provinces, the federal government could obtain absolute jurisdiction over the industry. ${ }^{179}$

It appears, however, that if this approach is to be used, a very clear and unambiguous declaration is necessary. The wording of the TDGA would not appear to meet this criteria.

174. Supran. 84.

175. R. v. Dominion Stores (1970) 30 N.R. 399 at 403 (S.C.C.).

176. R.v. Klassen (1960) 20 D.L.R. (2d) 406 (Man. C.A.).

177. R.v. Cosman's Furniture (1977) I W.W.R. 81 (Man. C.A.) decided this point regarding the Hazardous Products Act.

178. Emond, P. "The Case for a Greater Federal Role in the Environmental Protection Field: An Examination of the Pollution Problem and the Constitution" (1972) 10 Osgoode H.L.J. 647, 664.

179. This kind of declaration was utilized in Murphyv. C.P.R. (1958) S.C.R. 626 to gain federal control over the grain industry. 
It is very difficult to imagine the Act being upheld as emergency legislation, as it is neither expressly passed as such nor temporary in nature. ${ }^{180}$ The gradual implementation of the Act also erodes any possible argument that a national emergency is at hand.

Given the foregoing, it is difficult to justify federal encroachment of provincial powers under section 32(4) of the TDGA. Whether the provision will actually be used and upheld by the courts remains to be seen.

\section{REGULATIONS}

The process by which the regulations under the TDGA are to be made is rather innovative and unique. As is to be expected, the regulations are being drafted by the Transport of Dangerous Goods Branch of Transport Canada. The input of other federal and provincial agencies, industry, research groups and other interested or affected parties is also being actively elicited. ${ }^{811}$ Four drafts of the proposed regulations have been prepared, with each draft being subjected to increasingly stringent legal and scientific scrutiny. It is the extent to which non-governmental assistance is being utilized that makes the process unprecedented.

Another unusual procedure adopted is that after the regulations have been approved by the Joint Standing Committee, but before they are registered, they are to be published in Part I of the Canada Gazette. This is to ensure that ". . . reasonable opportunity shall be afforded to interested parties to make representations to the Minister . . ."182 Should such a representation result in changes to the regulations, the amended regulations need not be republished in Part I of the Canada Gazette prior to promulgation. ${ }^{183}$ Enactment of the regulations is to coincide with publication in the Canada Gazette, Part II.

Three aspects of this procedure are interesting. First, there is no criteria as to what constitutes a "reasonable opportunity" as there is in such statutes as the Environmental Contaminants Act, ${ }^{184}$ which specifies the time frame involved. The lack of a concrete time frame could be detrimental to effective comment on the proposed regulations, especially if the termination of the comment period is announced upon final publication. Too short a period will effectively stifle constructive criticism, while an overly generous period could give the impression that the government is dragging its feet.

Next, what form must these "representations" take? Will there be public hearings on the proposed regulations, or will submissions be restricted to written comments and suggestions forwarded to the Minister? The policy of Transport Canada has not been publicized. The types of representation allowed could have a great bearing on the process.

180. See, for example, Re Anti-Inflation Act (1976) 68 D.L.R. (3d) 452 (S.C.C.).

181. Supra n. 95 at 3-4.

182. TDGA, s. 22(1).

183. TDGA, s. 22(2)

184. Supra n. 43 at $5.5 ; 60$ day period 
Finally, what is the definition of "interested party"? If construed too widely, and if public interest is high, valuable time and effort could be wasted by hearing or examining repetitive submissions prepared by groups with similar concerns and goals. On the other hand, if the Minister interprets the phrase too narrowly, "interested party" could mean only those who are financially or operationally involved. While the expertise of manufacturers, transporters and emergency-response officials is welcomed, input definitely should not be limited to these sources. It is always a worry that those directly involved may allow financial matters to take precedence over safety concerns. Those without a pecuniary interest in the industry are sometimes more objective and, accordingly, are capable of providing insightful and extremely beneficial proposals. Fortunately, the current trend is to involve these more independent groups into the regulation-making process. ${ }^{185}$

Draft regulations were first published in Part I of the Canada Gazette in June of 1982. Discussion and comment are apparently still ongoing as to what further changes, if any, will be necessary. It is anticipated that regulations will be promulgated and come into force within the next few months.

\section{RECOMMENDATIONS AND CONCLUSIONS}

The preceding review of dangerous goods transportation regulation has included several comments regarding strengths and weaknesses of the law and the manner in which regulations are enforced. Legislation is currently in a state of flux, changing rapidly to meet new technical, social and political demands. However, as noted, room for further improvement still exists. Six recommendations are submitted towards this end:

1. Continued research: Although data is available on the quantities and types of dangerous goods carried in Canada, little research has been done on accidents involving these cargoes. Accident rates for different classes of goods, including information regarding accidents per ton-kilometer, type of cargo, extent of spill, cause of accident, resulting damage, cost of clean-up should be researched. This research should include a cost-benefit analysis of different regulatory schemes. Data of this sort would aid in making viable regulation of the industry more of a science than an art.

2. Uniform legislation: There are major differences among the various dangerous goods transportation laws currently in effect. As more provinces enact related statutes, further discrepancies may arise. Although the regime, as it currently exists, can work, it would be desirable to increase compatability between the Acts to facilitate more efficient administration of the system. The promotion of uniform legislation need not derogate from existing laws, nor need it delay the passage of similar statutes in other provinces. As problems arise, amendments to the Acts could be made. As well, a group such as the Uniform Law Conference of Canada or the Canadian Law Reform Commission could research the topic.

185. Anderson, R. D., "The Federal Regulation Making Process and Regulatory Reform 19691979" in Stanbury, W.T. Government Regulation: Scope, Growth, Process at 151 
3. Adoption of a generic definition of dangerous goods: It would seem that the adoption of a generic definition of dangerous goods, perhaps in conjunction with a system by which these substances could be scheduled, would save considerable effort in the future administration of these statutes. Given the number of new substances developed annually, it would be beneficial to institute a procedure under which any substance meeting or exceeding set criteria would be subject to regulation. This would be analogous to the approach adopted under the American Resource Conservation and Recovery Act.

4. Removal of the "due diligence" defence: This defence, recognized in Canada since $R$. v. Sault Ste. Marie ${ }^{186}$ poses significant problems in the prosecution of improper transportation of dangerous goods. It is submitted that the due diligence defence or even a standard of negligence is inappropriate for the more hazardous materials, given the serious nature of potential dangers. For these substances, should a spill occur a carrier or shipper should be liable in all instances, save "acts of God, acts of war, acts of a third party not employed, related to, or acting as agent of the carrier/shipper, or any combination of the above."

5. Fair and timely compensation for transport spill victims: Should a spill of dangerous goods cause injury or damage, it is imperative that remedial action to be taken as quickly as possible. The determination of liabilities, a long and involved process, can be done later. Insurance schemes can be designed to meet the need for quick compensation and later adjustments of liabilities. With an industry of this magnitude and with its incumbent risks, it is proposed that a joint industrygovernment insurance fund be established to compensate victims of transport related spills. It is beyond the scope of this paper to delve into the intricacies of assorted compensation schemes. However, it is submitted that the current manner of compensating those adversely affected by these activities is woefully inadequate. Major reforms are necessary to speed up the compensation process.

6. Adequate funding and personnel: If the new regime of regulating dangerous goods transportation is to be at all effective, it is necessary to have adequtely trained staff, in sufficient numbers. Only with suitable personnel enforcing compliance with the legislation will progress be made.

It is unfortunate that almost all environmental legislation has been passed in response to urgent, demanding situations. The Mississauga derailment proved crucial to the passage of the Transportation of Dangerous Goods Act. Rarely has foresight been the rationale for passage of these statutes. If it were, many problems could be avoided. As a result of past accidents, much progress has been made in regulating dangerous goods transportation. Hopefully more advances will be made without the need for new disasters to spark legislation. 